\title{
The Effects of Hypericum Crenulatum Polysaccharides on The Proliferation of Cancer Cells
}

Hypericum Crenulatum Polisakkaritlerinin Kanser Hücrelerinin Proliferasyonu Üzerine Etkileri

\author{
Oktay Özkan ${ }^{1}$ (D), Işıl Aydemir ${ }^{2}$ (D) , Ahmet Savran ${ }^{3}$ \\ 1 Department of Medicinal Pharmacology, Faculty of Medicine, Nigde Ömer Halisdemir University, Niğde/Turkey \\ 2 Department of Histology and Embryology, Faculty of Medicine, Nigde Ömer Halisdemir University, Niğde/Turkey \\ 3 Department of Biology, Faculty of Arts and Sciences, Nigde Ömer Halisdemir University, Niğde/Turkey
}

\section{ÖzeT}

Kanser tedavisinde amaç, sağlıklı hücrelere zarar vermeden tümör hücresi ölümünü indüklemek ve bu hücrelerin diğer organlara yayılmasını engellemektir. Metastaz durumunda, tedavi protokolleri yetersiz kalabilmektedir. Bu nedenle alternatif tedavi yöntemlerine başvurulmakta ve bu amaçla bitkisel ürünler yaygın olarak kullanılmaktadır. Çalışmamızda, Hypericum crenulatum polisakkaritlerinin meme kanseri hücre dizinlerinin proliferasyonu üzerindeki etkisini araştırmayı amaçladık. Hypericum crenulatum polisakkaritleri izole edilerek MCF-7 ve MDA-MB-231 meme kanseri hücrelerine farklı seyreltilerde uygulandı ve MTT metodu ile her iki hücre için IC50 dozları hesaplandı. Meme kanseri hücrelerine IC50 dozundaki polisakkaritler 24 saat süre ile uygulandı ve immünositokimyasal olarak metastaz ve proliferasyon belirteçleri PI3K, Akt-1 ve Erk-1/2 ile boyamaları yapıldı. Boyanmalar $\mathrm{H}$-score ile değerlendirilerek gruplar arasındaki farkı belirlemek amacıyla istatiksel analiz gerçekleştirildi. Hypericum crenulatum polisakaritlerinin her iki meme kanseri hücreleri üzerine MTT metodu ile toksik olduğu bulundu. PI3K, Akt-1 ve Erk1/2 boyanmaları incelendiğinde, uygulama gruplarında kontrol grubuna göre anlamlı bir azalma olduğu saptandı. MDA-MB-231 hücreleri ER (-) olduğundan, metastaz kabiliyetleri MCF-7 ER(+) hücrelerine kıyasla daha fazladır. Bu nedenle, polisakkaritlerin toksik etkisinin MCF-7 hücrelerinde daha yüksek olduğu bulundu. Sonuç olarak, bitkisel ürünlerin in vitro ortamda antiproliferatif etkilerinin yanında in vivo etkilerinin de ortaya konulması açısından çalışmalar yapılması gerekmektedir.

Anahtar Kelimeler: hypericum crenulatum, meme kanseri, proliferasyon, sitotoksisite

\section{ABSTRACT}

The goal in the cancer treatment is to induce tumor cell death without damaging healthy cells and to prevent the spread of these cells to other organs. In the case of metastasis, the cure protocols may be inadequate. Alternative methods are used to support treatment. For this purpose, herbal products are widely used. In our experiment, we aimed to investigate the effect of Hypericum crenulatum polysaccharides on the proliferation of breast cancer cell lines. Hypericum crenulatum polysaccharides were isolated and were exposed to the MCF-7 and MDA-MB-231 cells at different dilutions, then IC50 doses for each cell were calculated using MTT assay. Breast cancer cells were treated with IC50 doses of polysaccharides for 24 hours and immunocytochemistry was performed to evaluate the expressions of metastases and proliferation markers, PI3K, Akt-1 and Erk-1/2. The staining results were evaluated by $\mathrm{H}$-score and the difference between the groups was analyzed statistically. Hypericum crenulatum polysaccharides were found to be toxic to both breast cancer cells by MTT method. When PI3K, Akt-1 and Erk-1/2 markers of proliferation and metastasis were evaluated, it was seen that there was a significant decrease compared to the control group. Since MDA-MB-231 cells are ER (-), their invasion ability is over compared to MCF-7 ER (+) cells. For this reason, the toxic effect of polysaccharides was found to be higher in MCF-7 cells. As a result, in vivo studies are needed to be performed following the the antiproliferative effects of herbal products are found in vitro.

Keywords: hypericum crenulatum, breast cancer, proliferation, cytotoxicity

\section{INTRODUCTION}

Breast cancer is most common cancer type in women and has a high risk because of its metastatic properties. Especially, the treatment of hormone related breast tumors, such as estrogen receptor positive $(E R+)$ or progesterone receptor positive (PR+), is difficult.
Concurrently, the presence of molecules that allow tumor cells to multiply and spread to other organs also delays treatment of the breast cancer $(1,2)$. There are many signal molecules involved in tumorigenesis. The PI3K, Akt-1 and Erk-1/2 are the most important $(3,4)$. The increase in PI3K,

Yazışma Adresi/Address for Correspondence: Işıl Aydemir, PhD, Nigde Omer Halisdemir University, Faculty of Medicine, Department of Histology and 
Akt-1 and Erk-1/2 levels triggers the uncontrolled cell proliferation and causes cancer to start. Such molecules are targeted in cancer treatment. Previous studies have reported that inhibition of these molecules caused a decrease in the proliferation and proggression of tumor cells (5-7). Due to the difficulty of treatment, besides chemotherapy and surgery, alternative cure are seeked recently. The use of herbal products and compounds are among complementary alternative therapies (8-10).

In experimental studies, the cytotoxic effects of herbal products are investigated in vitro and in vivo conditions. The members of Hypericaceae plant family were searched and it was stated that they have effects such as antidepressant, antibacterial, anti-inflammatory and cytotoxic. Hyperforin, an acylphloro-glucinol-type compound, isolated from Hypericum crenulatum has antibiotic effect on several gram-positive bacteria (11) whereas 50 and $75 \mu \mathrm{L} / \mathrm{mL}$ of hypericin from Hypericum crenulatum has cytotoxic effect on MCF-7 breast cancer cells (12). Also photoactivated hypericin inhibited cell division in RINm5F insulinoma cells (IC50 dose: 105.97 nM9) (13). Another member of Hypericaceae family is Hypericum crenulatum is an endemic plant of Niğde region. Its compounds and biological effects have not yet been studied. In our experiment, we aimed to search the antiproliferative effects of polysaccharides isolated from Hypericum crenulatum on MCF-7 and MDA-MB-231 cells via metastasis and proliferation markers, PI3K, Akt-1 and Erk$1 / 2$.

\section{MATERIAL \& METHODS}

\section{Collection of plant and isolation of polysaccharides}

Hypericum crenulatum plant was gathered in term of July 2013 from the Bolkar Mountains within the boundaries of Niğde province. Its taxonomic classification was made by biologist Ahmet Savran. The leaf parts of the plant were used for polysaccharides isolation. The isolation method was performed according to the previously described protocol (14).

\section{Cell culture}

The MCF-7 and MDA-MB-231 breast cancer cell lines were purchased from ATCC, USA. Cells were cultured in RPMI1640 (F1213, Biochrom, Berlin Germany) media containing $10 \%$ fetal bovine serum (S0113, Biochrom, Berlin
Germany), 200mM L-glutamine (K0282, Biochrom, Berlin, Germany), $100 \mathrm{Ul} / \mathrm{ml}$. penicillin/streptomycin (A2213, Biochrom, Berlin, Germany) in the conditions of $370 \mathrm{C}$ and 5 $\%$ CO2 in a humidified atmosphere. They were grown for $70-80 \%$ confluency and then used for experiments.

\section{Cytotoxicity assay}

To detect IC50 dose of Hypericum crenulatum polysaccharides, 3-(4,5-dimethylthiazol-2-y1)-2,5diphenyltetrazolium bromide (MTT, M5655, Sigma, Steinheim, Germany) assay was used. For this purpose, cells were passage into 96 -well plate $(45 \times 103$ cells/well) and allowed to confluent (70-80\%) for $24 \mathrm{~h}$. The stock solution of polysaccharides was prepared as $100 \mathrm{mgr}$. polysaccharides $/ 1 \mathrm{~mL}$ ethanol. Cells were treated with the different dilutions of polysaccharides $(0,1 / 10,1 / 50,1 / 100$, $1 / 1000$ from stock solution) for $24 \mathrm{~h}$. Then media containing polysaccharides was discharged and $10 \mu \mathrm{L}$ MTT $(5 \mathrm{mg} / \mathrm{ml}$ in distilled water) and $100 \mu \mathrm{L}$ of fresh media were added to the cells. After 4 hours, MTT was removed and dimethyl sulphoxide (DMSO, A3672, AppliChem, Darmstadt, Germany) was put into the each well. The absorbance was measured at a wavelength of $570 \mathrm{~nm}$ using an UV visible spectrophotometer multiplate reader (ELx800UV, BioTek). The experiment was repeated 3 times for each concentration (15).

\section{Immunocytochemistry}

For immunocytochemical staining, MCF-7 and MDA-MB-231 breast cancer cells were cultured into the 24-well plates ( $2.5 \times 105$ cells/per well) for $24 \mathrm{~h}$. Cells were treated with the IC50 dose of Hypericum crenulatum polysaccharides for 24 h. Then cells were fixed in 4\% paraformaldehyde in PBS at +4oC for $30 \mathrm{~min}$ and 0.1\% Triton X-100 (A4975, AppliChem, Darmstadt, Germany) was used for permeabilization. Following washing in PBS three times for $5 \mathrm{~min}$, endogenous peroxidase activity was inhibited with $3 \%$ hydrogen peroxide (1 08600, Merck, Darmstadt, Germany). Cells were incubated with primary antibodies: anti- PI3K (sc1637, Santa Cruz Biotechnology) ve anti- Akt-1 (sc-271149, Santa Cruz Biotechnology) and anti-Erk-1/2 (sc-514302, Santa Cruz Biotechnology) at $+40 \mathrm{C}$ overnight. For negative control, primary antibodies were not applied to cells. After washing in PBS, the secondary antibodies, biotinylated secondary antibodies and peroxidase-conjugated 
streptavidin (Histostain kit, 85-9043, Zymed, Carlsbad, USA), were used. Cells were dyed with diaminobenzidine/hydrogen peroxide (DAB, 00-2014, Invitrogen, CA, USA) to make the immunoreactivities visible and counterstaining was performed with Mayer's hematoxylin (800-729-8350, ScyTek, UT, USA). Cells were mounted with aqueous medium (K002, DBS, Pleasanton, USA). Samples were evaluated under camera attached (SC50, Olympus, Germany) light microscope (IX71 invertedflorescence-phase microscope) (Olympus, Japan). Experiments were repeated three times (16).

\section{Statistical analysis}

The intensities of immunocytochemical staining were determined as no staining (0), weak (+), moderate $(++)$ and strong $(+++)$ respectively and cells were counted for each intensity in five different fields. The $\mathrm{H}$-score was calculated by formula $\mathrm{H}$-Score $=\Sigma \mathrm{Pi}$ (intensity of staining +1 ). $\mathrm{Pi}$ means the percentage of stained cells for intensity, varying from $0 \%$ to $100 \%$. The $\mathrm{H}$-score was evaluated by at least two observers independently. The values for $<0.05$ were considered statistically significant. The results were analyzed by repeated-measures of the ANOVA test. The Tukey-Kramer multiple comparisons test was used to expressed differences amongst the mean values (mean \pm Standard deviation) $(16,17)$.

\section{RESULTS}

\section{Cytotoxicity assay}

The cytotoxic effects of Hypericum crenulatum polysaccharides were determined by MTT assay and IC50 doses for MCF-7 and MDA-MB-231 breast cancer cell lines were calculated as $12.5 \mu \mathrm{g} / \mathrm{ml}$ and $10.25 \mu \mathrm{g} / \mathrm{ml}$, respectively (Figure 1).

Figure 1.

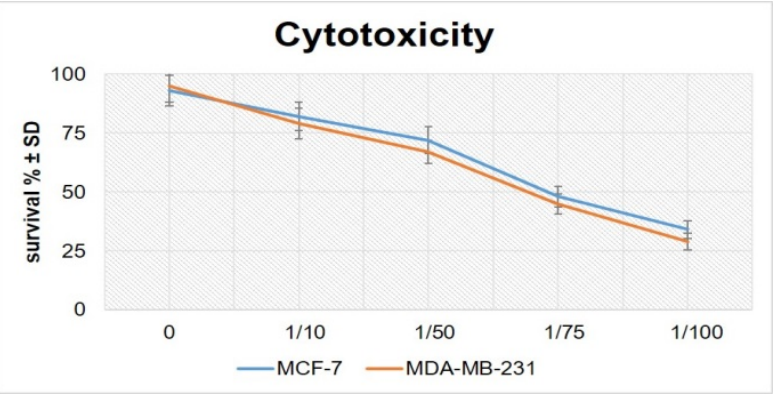

The results of MTT assay for IC50 doses of Hypericum crenulatum polysaccharides on MCF-7 and MDA-MB-231 breast cancer cell lines for $24 h$.

\section{Immunocytochemical results}

After application of Hypericum crenulatum polysaccharides IC50 doses for both MCF-7 and MDA-MB-231 breast cancer cell lines, immunocytochemical procedure was performed using proliferation markers PI3K, Akt-1 and Erk-1/2. The Hscore evaluations were compared for each cell lines and markers. It was found that polysaccharides were toxic for both breast cancer cell lines via proliferation markers.

Polysaccharides reduced proliferation markers in MCF-7 cells compared to control group (Figure 2). The decrease in Akt-1 immunoreactivity was more obvious according to control group $(* * * P<0.001)$. In the Erk-1/2 immunoreactivity, the difference between the control group and polysaccharides group was lower $(* * P<0.01)$ than the other groups of PI3K and Akt-1 markers (Figure 3).

Figure 2.

\section{MCF-7}

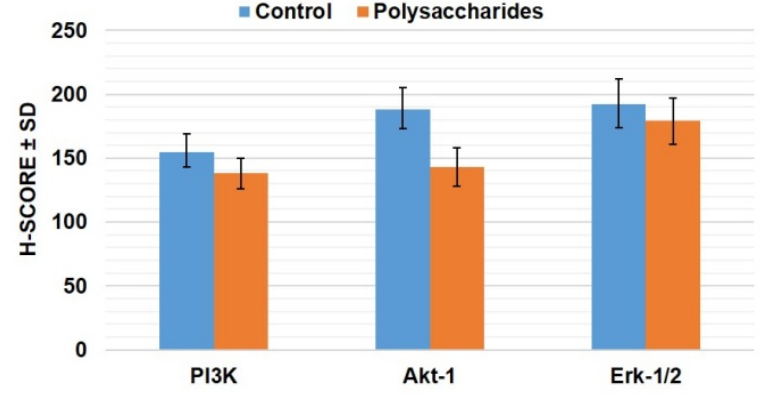

$\mathrm{H}$-score analysis of immunocytochemical staining of PI3K, Akt-1 and Erk-1/2 in MCF-7 breast cancer cells after application of Hypericum crenulatum polysaccharides.

Figure 3.

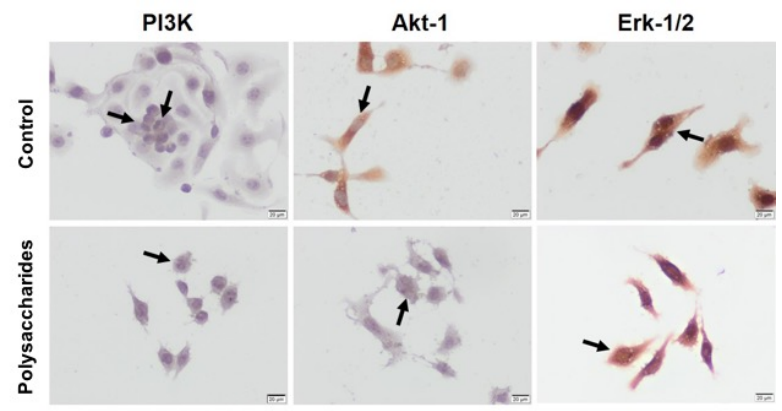

The images of immunocytochemical stainings of PI3K, Akt-1 and Erk-1/2 in MCF-7 breast cancer cells after application of Hypericum crenulatum polysaccharides. Arrows: immunopositive cells, Scale bars: $20 \mu \mathrm{m}$. 
In MDA-MB-231 cells, the immunoreactivities of PI3K, Akt-1 and Erk-1/2 were greater than the polysaccharides group (Figure 4 and 5), whereas they were significantly decreased in the polysaccharides group. Especially polysaccharides prominently decreased the immunoreactivity of Erk-1/2 $(* * * P<0.001)$.

When the effect of the polysaccharides drug on two different breast cancer cells is examined, Erk-1/2 was more repressed by polysaccharides in MDA-MB-231 cells $(* * * P<0.001)$. There was no difference between the two cells in terms of the immunoreactivity of PI3K $(P>0.05)$. The distribution of Erk-1/2 immunoreactivity was similar in both cells.

\section{Figure 4.}

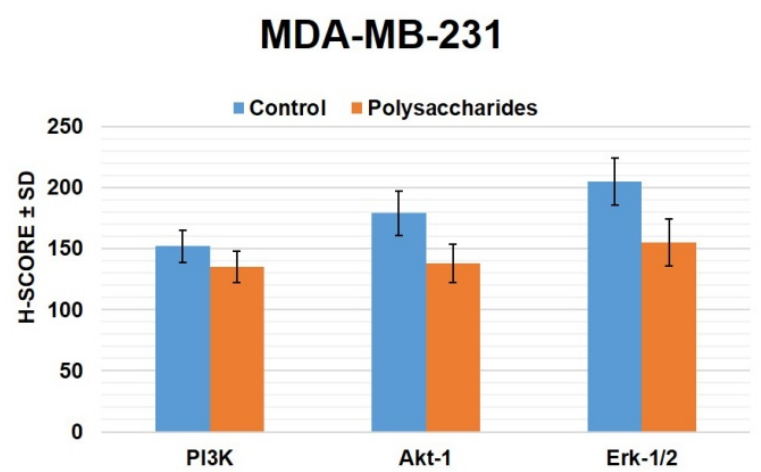

$\mathrm{H}$-score analysis of immunocytochemical stainings of PI3K, Akt-1 and Erk-1/2 in MDA-MB-231 breast cancer cells after application of Hypericum crenulatum polysaccharides.

\section{Figure 5.}

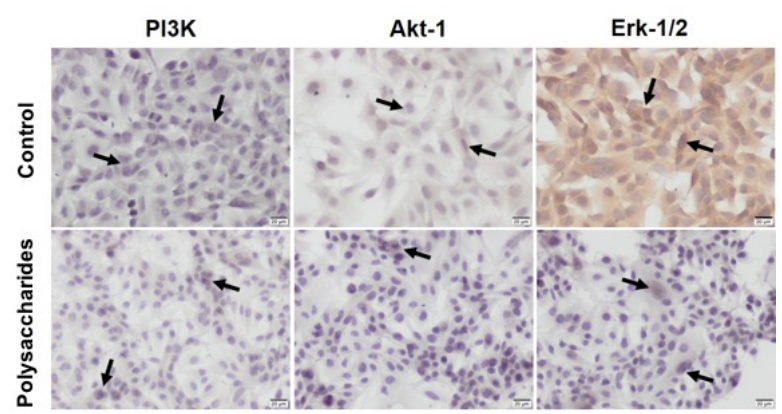

The images of immunocytochemical stainings of PI3K, Akt-1 and Erk-1/2 in MDA-MB-231 breast cancer cells after application of Hypericum crenulatum polysaccharides. Arrows: immunopositive cells, Scale bars: $20 \mu \mathrm{m}$.

\section{DISCUSSION}

Here we stated that Hypericum crenulatum polysaccharides have inhibitory effect on the proliferation of MCF-7 and MDA-MB-231 breast cancer cells in vitro condition via proliferative markers PI3K, Akt-1 and Erk-1/2. In these markers, there was a significant decrease compared with the un-treated group. In the current study, we used Hypericum crenulatum polysaccharides that had not been studied before was used. But the other species belonged to the genus of Hypericum, have shown to have an antiproliferative effect on tumor cells in vitro conditions (11, $12,18-23)$.

Hyperforin from Hypericum perforatum, was toxic for MCF7, MDA-MB-468 and MT-450 mammary carcinoma cell lines at IC50<5 $\mu \mathrm{M}$ (11). Hypericin, another agent extracted from Hypericum perforatum, caused cell death in MCF-7 cells at a dose of $\geq 50 \mu \mathrm{l} / \mathrm{ml}$ (12). In another study, IC50 dose of hypericin for MCF-7 cells was found as $5 \mu \mathrm{g} / \mathrm{ml}$ for $24 \mathrm{~h}$ and $0.5 \mu \mathrm{g} / \mathrm{ml}$ for $48 \mathrm{~h}$ (18). Concurrently, hypericin activated with light, triggered the apoptotic pathways on $\mathrm{A} 375$, $501 \mathrm{mel}$ and UCT Mel-1 melanoma cells. It was indicated that extrinsic pathway was occured via caspase- 8 in A375 cells, whereas the intrinsic pathway was initiated by caspase- 8 and PARP in UCT Mel-1 cells (19). The extract of Hypericum scabrum, has also been shown to have a cytotoxic effect on some tumor cells, such as MCF-7 human breast carcinoma cells, A549 non-small cell lung carcinoma, HepG-2 hepatocellular carcinoma and HT-29 colorectal carcinoma cells $(20,21)$. The methanolic extract of Hypericum salsugineum has been evaluated for its antiproliferative and cytotoxic effects on MCF-7 and MDAMB-231 breast cancer cell lines. In both cells, the methanolic extract of Hypericum salsugineum at dose of $350 \mu \mathrm{g} / \mathrm{ml}$, repressed the cell migration and colony formation (22). In our study, we found that the Hypericum crenulatum polysaccharides has a cytotoxic effect on MCF7 and MDA-MB-231 and detected the IC50 dose of Hypericum crenulatum polysaccharides for MCF-7 and MDA-MB-231 cells as $12.5 \mu \mathrm{g} / \mathrm{ml}$ and $10.25 \mu \mathrm{g} / \mathrm{ml}$, respectively.

The presence of proliferative markers plays an important role in the development and progression of cancer. $\mathrm{PI} 3 \mathrm{~K} / \mathrm{Akt} / \mathrm{mTOR}$ signalling pathway has a crucial role for progression and survival of tumor cells. In the studies about the cancer, it is intended to be suppressed the signal molecules of PI3K/Akt/mTOR pathway by anticancer agents or herbal extracts, respectively $(24,25)$. It was reported that the compound of hyperoside found in the genus of Hypericum and Crataegus, induced autophagy in A549 non- 
small cell lung cancer cells. It was suggested that there was a relationship between the autophagy and inhibition of the $\mathrm{PI3K} / \mathrm{Akt} / \mathrm{mTOR}$ signaling pathway and also induction of Erk1/2 (21). In the current study, we determined that there was a significant reduced expression of PI3K, Akt-1, Erk-1/2 by Hypericum crenulatum polysaccharides in MCF-7 and MDA-MB-231 breast cancer cell lines.

\section{CONCLUSION}

In our experiment, Hypericum crenulatum polysaccharides have cytotoxic effect on both MCF-7 and MDA-MB-231 breast cancer cell lines in vitro condition. After the application of Hypericum crenulatum polysaccharides, the antiproliferative effect was ascertained by the decrease in PI3K, Akt-1, Erk-1/2 markers. The further studies of in vivo cancer model are needed to establish the antiproliferative effect of Hypericum crenulatum polysaccharides.

Yazarlar arasında çıkar çatışması yoktur.

The author declares no conflict of interest.

Finansal destek yoktur

The author(s) received no financial support for the research, authorship, and/or publication of this article.

doi: https://doi.org/10.33713/egetbd.647464

\section{REFERENCES}

1. Hasegawa T, Adachi R, Iwakata $H$, Takeno $T$, Sato $K$, Sakamaki T. ErbB2 signalingepigenetically suppresses microRNA-205 transcription via Ras/Raf/MEK/ERK pathway in breast cancer. FEBS Open Bio 2017; 7(8):1154-1165. doi:10.1002/2211-5463.12256.

2. Gagliato DM, Jardim DL, Marchesi MS and Hortobagyi GN. Mechanisms of resistance and sensitivity to anti-HER2 therapies in HER2+ breast cancer. Oncotarget 2016; 7, 64431-64446.

3. Liu S, Chen S, Yuan W, Wang H, Chen K, Li D, Li D. PD1/PD-L1 interaction up-regulates MDR1/P-gp expression in breast cancer cells via PI3K/AKT and MAPK/ERK pathways. Oncotarget 2017; 8(59):99901-99912. doi:10.18632/oncotarget.21914.

4. Han R, Gu S, Zhang Y, Luo A, Jing X, Zhao L, Zhao X, Zhang $L$. Estrogen promotes progression of hormone-dependent breast cancer through CCL2-CCR2 axis by upregulation of Twist via PI3K/AKT/NF-KB signaling. Sci Rep 2018; 8(1):9575. doi: 10.1038/s41598-018-27810-6.
5. Weigelt B, Warne PH and Downward J. PIK3CA mutation, but not PTEN loss of function, determines the sensitivity of breast cancer cells to mTOR inhibitory drugs. Oncogene $2011 ; 30,3222-3233$.

6. Adamczyk A, Niemiec J, Janecka A, Harazin- Lechowska A, Ambicka A, Grela-Wojewoda A, Domagala-Haduch M, Cedrych I, Majchrzyk K, Kruczak A et al. Prognostic value of PIK3CA mutation status, PTEN and androgen receptor expression for metastasis-free survival in HER2-positive breast cancer patients treated with trastuzumab in adjuvant setting. Pol J Pathol 2015; 66, 133-141.

7. Qin H, Liu L, Sun S, Zhang D, Sheng J, Li B, Yang W. The impact of PI3K inhibitors on breast cancer cell and its tumor microenvironment. PeerJ 2018; 6:e5092. doi: 10.7717/peerj.5092.

8. Franco $P$, Rampino $M$, Ostellino $O$, Schena $M$, Pecorari $G$, Garzino Demo P, Fasolis M, Arcadipane F, Martini S, Cavallin C, Airoldi M, Ricardi U. Management of acute skin toxicity with Hypericum perforatum and neem oil during platinumbased concurrent chemo-radiation in head and neck cancer patients. Med Oncol 2017; 34(2):30. doi: 10.1007/s12032017-0886-5.

9. Werthmann $P G$, Inter $P$, Welsch $T$, Sturm AK, Grützmann R, Debus M, Sterner MG, Kienle GS. Long-term tumor-free survival in a metastatic pancreatic carcinoma patient with FOLFIRINOX/Mitomycin, high-dose, fever inducing Viscum album extracts and subsequent R0 resection: A case report. Medicine (Baltimore) 2018; 97(49):e13243. doi: 10.1097/MD.0000000000013243.

10. Costea T, Hudiță A, Ciolac OA, Gălățeanu B, Ginghină O, Costache M, Ganea C, Mocanu MM. Chemoprevention of Colorectal Cancer by Dietary Compounds. Int J Mol Sci 2018; 19(12). pii: E3787. doi: 10.3390/ijms19123787.

11. Schempp CM, Kirkin V, Simon-Haarhaus B, Kersten A, Kiss J, Termeer CC, Gilb B, Kaufmann T, Borner C, Sleeman JP, Simon JC. Inhibition of tumour cell growth by hyperforin, a novel anticancer drug from St. John's wort that acts by induction of apoptosis. Oncogene 2002; 21(8):1242-50.

12. Ocak Z, Acar M, Gunduz E, Gunduz M, Demircan K, Uyeturk $U$, Ozlü T. Effect of hypericin on the ADAMTS-9 and ADAMTS- 8 gene expression in MCF7 breast cancer cells. Eur Rev Med Pharmacol Sci 2013; 17(9):1185-90.

13. Yi J, Yang $X$, Zheng $L$, Yang G, Sun L, Bao Y, Wu Y, Huang $Y$, Yu C, Yang SN, Li Y. Photoactivation of hypericin decreases the viability of RINm5F insulinoma cells through reduction in JNK/ERK phosphorylation and elevation of caspase-9/caspase-3 cleavage and Bax-to-Bcl-2 ratio. Biosci Rep 2015; 35(3). pii: e00195. doi: 10.1042/BSR20150028.

14. You Lv , Xingbin Yang, Yan Zhao, Yun Ruan, Ying Yang, Zhezhi Wang. Separation and quantification of component monosaccharides of the tea polysaccharides from Gynostemma pentaphyllum by HPLC with indirect UV 
detection. Food Chemistry 2009; 742-746.

15. Deliloglu-Gurhan I, Tuglu I, Vatansever HS, Ozdal-Kurt F, Ekren $H$, Taylan $M$, Sen BH. The effect of osteogenic medium on the adhesion of rat bone marrow stromal cell to the hydroxyapatite. Saudi Med J 2006; 27(3):305-11.

16. Ozdal-Kurt F, Tuğlu I, Vatansever HS, Tong $S$, Şen BH, Deliloğlu-Gürhan SI. The effect of different implant biomaterials on the behavior of canine bone marrow stromal cells during their differentiation into osteoblasts. Biotech Histochem 2016; 91(6):412-22, 2016. doi: 10.1080/10520295.2016.1183819.

17. Ozbilgin K, Karaca F, Turan A, Köse C, Vatansever S, Ozcakir T. 2015. The higher heparin-binding epidermal growth factor (HB-EGF) in missed abortion. Taiwan. J. Obstet. Gynecol 2015; 54 (1), $13 e 18$.

18. Mirmalek SA, Azizi MA, Jangholi $E$, Yadollah-Damavandi S, Javidi MA, Parsa Y, Parsa T, Salimi-Tabatabaee SA, Ghasemzadeh Kolagar H, Alizadeh-Navaei R. Cytotoxic and apoptogenic effect of hypericin, the bioactive component of Hypericum perforatum on the MCF-7 human breast cancer cell line. Cancer Cell Int 2016; 16:3. doi: 10.1186/s12935 016-0279-4.

19. Kleemann B, Loos B, Scriba TJ, Lang D, Davids LM. St John's Wort (Hypericum perforatum L.) photomedicine: hypericin-photodynamic therapy induces metastatic melanoma cell death. PLoS One 2014; 9(7):e103762. doi: 10.1371/journal.pone.0103762.

20. Hamzeloo-Moghadam M, Khalaj A, Malekmohammadi M. Cytotoxic Activity and Apoptosis Induction of Hypericum scabrum L. Iran Red Crescent Med J 2015; 17(10):e19453. doi: 10.5812/ircmj.19453.

21. Fu T, Wang L, Jin XN, Sui HJ, Liu Z, Jin Y. Hyperoside induces both autophagy and apoptosis in non-small cell lung cancer cells in vitro. Acta Pharmacol Sin 2016; 37(4):505-18. doi: 10.1038/aps.2015.148.

22. Bender O, Llorent-Martínez EJ, Zengin G, Mollica A, Ceylan R, Molina-García L, Fernández-de Córdova ML, Atalay A. Integration of in vitro and in silico perspectives to explain chemical characterization, biological potential and anticancer effects of Hypericum salsugineum: A pharmacologically active source for functional drug formulations. PLoS One 2018; 13(6):e0197815. doi: 10.1371/journal.pone.0197815.

23. Borawska MH, Naliwajko SK, Moskwa J, MarkiewiczŻukowska R, Puścion-Jakubik A,Soroczyńska J. Antiproliferative and anti-migration effects of Polish propolis combined with Hypericum perforatum L. on glioblastoma multiforme cell line U87MG. BMC Complement Altern Med 2016; 16:367. doi: 10.1186/s12906-016-1351-2.

24. Sun B, Wang G, Liu H, Liu P, Twal WO, Cheung H, Carroll SL, Ethier SP, Mevers EE, Clardy J, Roberts T, Chen C, Li Q,
Wang L, Yang M, Zhao JJ, Wang Q. Oridonin inhibits aberrant AKT activation in breast cancer. Oncotarget 2018; 9(35):23878-23889. doi: 10.18632/oncotarget.24378.

25. Sun X, Ma X, Li Q, Yang Y, Xu X, Sun J, Yu M, Cao K, Yang $L$, Yang $G$, Zhang G, Wang $X$. Anti-cancer effects of fisetin on mammary carcinoma cells via regulation of the $\mathrm{PI3K} / A k t / m T O R$ pathway: In vitro and in vivo studies. Int J Mol Med 2018; 42(2):811-820. doi: 10.3892/ijmm.2018.3654 